\title{
Evaluation of Service Quality in a Call Center From the Employees Perspective
}

DOI: $10.26466 /$ opus. 881444

$*$

\section{Aysel Cetindere Filiz *- Merve Nur Atalar **}

* Dr. Öğr. Üyesi, Ondokuz Mayıs University, Faculty of Economics and Ad. Sci., Samsun/Türkiye E-Posta: aysel.cetindere@omu.edu.tr

ORCID: 0000-0003-1810-5559

** Master Student, Ondokuz Mayis University, Graduate School of Social Sciences, Samsun/Turkey E-Posta: mnuratalar@gmail.com

ORCID: 0000-0001-5711-340X

\begin{abstract}
With the acceleration of competition, call centers, which have started to attract intense interest by businesses, are preferred in terms of providing services easily and at the speed desired by the customers. Call centers are service organizations designed to establish fast and long-term relationships with customers through various communication tools. Developing a common understanding of quality in call centers, which are the first contact point with the customer and have different standards in different regions, can be quite complicated because the services are abstract and the customers are included in the process. For this reason, the service quality should be measured and improved continuously. The purpose of this study is to evaluate the service quality of a call center as perceived by its employees using the servqual scale. The data was obtained by field study with the adapted servqual scale from the call center which is affiliated with a state bank. In this paper employees' perceptions and expectation levels were measured according to tangibles, reliability, responsiveness, assurance and empathy dimensions and the gap scores (perceived-expectation) obtained from the measurement result were evaluated. Factor analysis, frequency distributions, correlation and paired $t$-tests were also used in the study. As a result of the analysis, statistically significant relationships were found in the subdimensions of concrete features, reliability, responsiveness and assurance.
\end{abstract}

Keywors: Service quality, call center, employees, servqual scale. 


\section{Bir Çağrı Merkezinde Hizmet Kalitesinin Çalışanlar Perspektifinden Değerlendirilmesi}

Öz

Rekabetin hız kazanmasıyla birlikte işletmeler tarafindan yoğun bir şekilde ilgi görmeye başlayan çağr merkezleri, kurumların kolaylıkla ve müşterilerin istediği hızda hizmet sunması bakımından tercih edilmektedir. Çă̆rı merkezleri çeşitli iletişim araçlar ile müşterilerle hızlı ve uzun vadeli ilişkiler kurmak üzere tasarlanmış hizmet kuruluşlarıdır. Müşteri ile ilk temas noktası olan ve farklı bölgelerde farklı standartlara sahip çağrn merkezlerinde ortak bir kalite anlayışı geliştirmek, hizmetlerin soyut olması ve müşterilerin de sürece dahil edilmesi nedeniyle oldukça karmaşık olabilmektedir. Bu nedenle hizmet kalitesinin ölçülmesi ve sürekli olarak iyileştirilmesi gerekmektedir. Bu çalışmanın amacı, servqual ölçeğini kullanarak bir çağr merkezinin hizmet kalitesini çalışanlarının algıladığı şekilde değerlendirmektir. Veriler, bir devlet bankasına bağhl çağrn merkezinden uyarlanmış servqual ölçeği ile saha çalışması yapılarak elde edilmiştir. Çalışanların algı ve beklenti düzeyleri somut özellikler, güvenilirlik, heveslilik, güvence ve empati boyutlarına göre ölçülmüş ve ölçüm sonucundan elde edilen boşluk puanları (algılanan-beklenti) değerlendirilmiştir. Çalışmada ayrıca faktör analizinden, frekans dağglımlarından, korelasyon ve eşleştirilmiş t-testlerinden yararlanılmıştır. Yapılan analizler sonucunda somut özellikler, güvenirlik, heveslilik ve güvence alt boyutlarnda istatistiksel olarak anlaml ilişkiler bulunmuştur.

AnahtarKelimeler: Hizmet kalitesi, çağrı merkezi, çalışanlar, servqual ölçeği. 


\section{Introduction}

The competitive pressures faced by many growing and rapidly developing service industries have led to efforts to make service businesses more efficient. According to data from Turkey Statistical Institute to evaluate the development of the service sector in Turkey, the services sector in terms of economic activity branches, the share of Gross Domestic Product (GDP), while 48.5\% in 1998, in 2018 it increased to 54.2\% (Tüik, 2018). Considering this ratio, it is seen that the service sector is an important and developing area for our country. Services are offered to customers in a short time due to their nature, but success can be achieved with longterm relationships in this sector. The quality of the services provided in a short time is a fundamental factor in achieving sustainable success.

Globalization of markets, shortening of product life-cycles, more demanding customers and increased competition are some of the trends requiring the use of advanced technologies in business competition. The capability for more frequent and faster communication with current and potential customers, vendors and business partners is of critical importance in today's business climate. Technological advances are the foundation for deriving such capabilities. Given limited corporate resources on the one hand and more demanding customers on the other, reducing customer acquisition costs is a priority. Call centers make it possible to reduce these costs (Prabhaker, Sheehan and Coppett, 1997, p.222).

In recent years, both in the number of call centers in the world it has been a significant increase in both Turkey. According to 2019 Market Research regarding Call Center Industry in Turkey, the market size of the sector has increased by $21,5 \%$ compared to last year and reached 7,5 billion TL. The call center sector, and create added value and jobs created by it has become one of the most important business areas for Turkey's economy. Call center is defined as "a coordinated system consisting of people, processes, technology and strategies in which the resources of the organization and different communication channels are effectively integrated in order to create value for the customer and the organization". In simpler terms, the call center is a mechanism that enables customers and organizations to communicate with telephone, fax, e-mail, 
voice response systems, internet-based systems and even video phones (Gümüş, 2002, p.134). Call centers are strategically important to many organizations because they are often the major customer interface, and they can provide a service-based competitive edge using high volume, low cost delivery via telephones. To address both budgetary and service priorities, managers are concerned with customization of their products and standardization of their processes. Customization is necessary to meet the ever-increasing expectations of consumers and to provide high levels of service quality and subsequent customer loyalty. Standardization enables employee training, consistent responses to customer enquiries, and the ability to cater to a mass market. In meeting both cost and service goals, frontline employees are usually expected to adhere to strict efficiency targets, and to accept high levels of monitoring and control while managing customer service interactions. This presents a unique and contradictory service environment (Dean and Rainnie, 2009, p.326). Lovelock (1999) explained the concept of service in two ways. The first of these is that the service is the action or performance that one party offers to the other. According to this approach, although the process may depend on a physical product, performance is not tangible and does not result in having any of the factors of production. In the second approach, services are economic activities that create value and provide benefits for customers at a certain point in time and at a certain point as a result of making a change that the customer wants. According to both approaches, service quality refers to the extent to which a service meets customer expectations. While it is easier to define a concrete product quality, it can be much more difficult to define service quality, especially because of its abstract nature. The consumer evaluates the quality of a product according to many tangibles such as style, color, label, packaging, but there are few tangible elements when purchasing a service. In most cases, the tangible elements are limited to the service provider's physical facilities, equipment and personnel.

There are visible and invisible parts in the systems established to provide service. Some authors use the terms "front office" and "back office" to refer to the visible and invisible parts of the operation. Accordingly, the front office is the visible part and the back office is the invisible part of the service (Lovelock, 1999, p.60). Front office employees' opinions 
should be taken into account in improving the service quality, since front office employees affect the level of service quality through interaction with customers (Munhurrun, Naidoo and Bhiwajee, 2009, p.543). In call centers operating in the service sector, the relationships of front office employees with customers significantly affect the service quality. Call centers, which emerged as the product of the tremendous developments in information and communication technologies, can be defined as a system that allows the use of various contact channels such as telephone, internet (e-mail, online chat), fax and mail for all groups(customers, suppliers, dealers, etc.) that the company wants to contact with, directs incoming calls to a single center, and where many highly skilled personnel work together (Sariyer, 2007, p.474). The features that call centers should have to provide a world-class service are as follows (Gümüş, 2002, p.136):

- Giving customers the right to choose; customers want to retain the choice of determining what kind of service they expect. The service provided must be in line with their wishes, needs and standards.

- Ensuring access to the call center anytime and anywhere; accessibility from anywhere must be ensured 24 hours a day, 7 days a week and 52 weeks a year.

- Ensuring that customers can choose the service they want when they call their call center; a call center that allows customers to choose the service offered by their automated service menus or call center authorities.

- Personalization of an incoming phone call; every customer who reaches the call center should be provided with a service that will make them feel that they are being served only.

- Knowing customers well; employees must have all the knowledge and skills required in line with customer needs.

- To ensure that employees provide the best service; it should be ensured that call center employees have the knowledge, skill and technical equipment required for good and quality service.

- Aiming for the best and evaluating performance for this purpose; the only standard in call centers is 'excellence'. In order to achieve this perfection, success must be measured after each process and at certain intervals. 
According to Osahon and Kingsley (2016), two approaches are used in the evaluation of the service quality of organizations, from the outside in and the inside out. In the outside-in approach, the focus is on the external customers (external service quality) of the institution. In the inside-out approach, the focus is on the internal customers, that is, internal processes and employees. According to this approach, the perspectives of both customers and employees and their evaluations about the institution are effective on the service quality. Employees working in call centers according to various job positions play an important role in service delivery and service quality. Because the service quality develops depending on the relations of the service personnel working on the front line with the customers. When the studies about service quality in call centers are evaluated; Munhurrun et al. (2009) used servqual model to discuss the perceptions of service quality, satisfaction and intention of continuing to work in a call center. Jaiswal (2008) stated that the perceived service quality of call centers should be measured systematically and comprehensively as a result of a qualitative research including indepth interviews in order to understand current practices for measuring customer satisfaction and service quality in call centers in India. Dean and Rainnie (2009) put forward the views of call center employees about organizational factors that affect their ability to provide service quality to customers. Chicu et al. (2016) analyzed the determinants of customer satisfaction (management strategies, human resources management practices and results, employee behavior and efficiency, and service quality) in the call center. Kocabas (2017) evaluated the effects of the image of customer representatives at the call center on customer satisfaction. Taşkın and Taşkın (2018) investigated the impact of call center employees' behavior on customer satisfaction and made strategic recommendations to businesses in customer relationship management.

When the studies evaluating the service quality for call centers in the literature are examined, it is seen that the perceptions of the employees responsible for the customer service process are not adequately addressed. Especially the perceptions of the front line employees regarding the service quality significantly affect the service quality provided to the customer. Therefore, the aim of the study is to reveal the perspectives of the personnel providing services within the scope of the perceived and 
expected service quality levels in order to help managers in determining the measures to be taken to improve the quality of the service provided to the customer. Evaluations made according to the data to be obtained from the perspective of service personnel working on the front line at the call center will make a significant contribution to determining the measures that managers should take in order to continuously improve and diagnose the service features. At the same time, the importance levels of the factors that are effective in improving the service quality in the call center according to the perspective of the employees were also discussed in this study.

\section{Method}

This study was approved by the Universtiy's ethics committee (Date: 30.10.2020, Number: 2020/715). The study was carried out in a call center serving a state bank. Services offered in the call center; it covers many transactions such as lost/stolen card notifications, password transactions, credit card transactions, debit card transactions, telephone banking services, internet banking technical support services. The satisfaction of customers who receive support from the call center in order to benefit from the services offered by the bank is very important. With the increasing number of satisfied customers and continuing to be a customer of the bank in the future, the bank will continuously gain profit. For this reason, call center managers should be able to benefit from the opinions of both their customers and employees while ensuring customer satisfaction, determining quality service policies and providing a constantly improving service quality to their customers. It is necessary to take into account the contribution of the front office employees, who are in oneon-one contact with customers and who have an important position in ensuring customer satisfaction, to continuously improve the service quality.

Among service organizations surveyed to measure service quality, call centers received little attention, especially from the perspective of employees. In this study, the quality of service Parasuraman et al. (1991) based on the servqual scale developed from the perspective of front office workers. The servqual is based on the "The Gap Theory of Service 
Quality". According to this theory, inputs are provided to measure service quality, establish service standards, and develop strategies to fill the gaps between current and required service quality levels. Servqual scale used in the study consists of four parts. The first part includes demographic information (gender, age range, education level, job position and duration, and past experience in the same sector) of the participants. In the second and third sections, there are sections where expectations and perceptions are measured, respectively, according to service quality dimensions (tangibles, reliability, responsiveness, assurance and empathy). In the study, a five Point Likert Scale was used for the expectation and perception evaluations for each of the 22 items ("1 Strongly disagree".... "5 Strongly agree"). In the fourth and last part of the questionnaire, employees were asked to evaluate the factors that are effective in improving the service quality at the call center over 100 points according to their importance level. These evaluations are important in terms of revealing the order of importance of the factors that are effective in improving the service quality according to the perspective of the employees. The questionnaire was carried out for call center employees of a public bank in November and December 2020. The survey questions were distributed to approximately 500 people working in the institution and feedback was received from 235 people. SPSS 26.0 was used to analyze the data. Reliability analyzes were performed according to Cronbach's Alpha coefficients to evaluate the consistency of each dimension in the scale within the scope of both perceived and expected service quality. In addition, the total variance of the survey results was measured by factor analysis in the study. Descriptive statistical analyzes were performed with paired ttests to evaluate the statistical significance of the call center employees' expectation and perception scores. The relationships between the expected and perceived service quality of the participants and their demographic characteristics were revealed by correlation analysis. At the end of the study, the average of the questions asked to the employees in order to evaluate the importance levels of the factors that are effective in improving service quality at the call center are included. The conceptual model of the research is shown in figure 1 . 


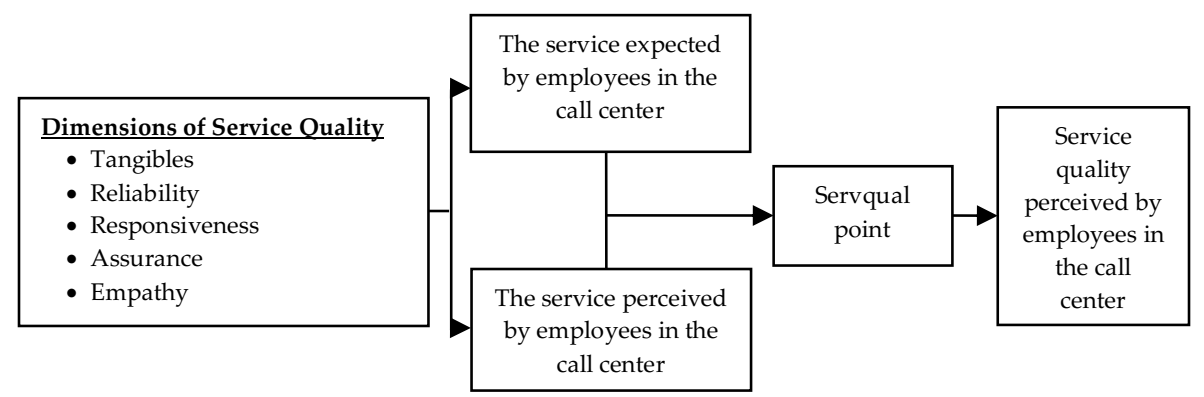

Figure 1. Conceptual model of the research

\section{Findings}

The demographic characteristics of a total of 235 employees participating in the survey are shown in table 1.

Table 1. Demographic characteristics of the participants

\begin{tabular}{|c|c|c|c|c|c|}
\hline Gender & $\mathbf{N}$ & $\%$ & Experience & $\mathbf{N}$ & $\%$ \\
\hline Women & 132 & 56,2 & Yes & 80 & 34 \\
\hline Men & 103 & 43,8 & No & 155 & 66 \\
\hline Age range & & & Education level & & \\
\hline $18-25$ & 68 & 28,9 & High school & 29 & 12,3 \\
\hline $26-32$ & 131 & 55,7 & Associate degree & 85 & 36,2 \\
\hline 33- 40 & 34 & 14,5 & Undergraduate & 107 & 45,5 \\
\hline 40 and over & 2 & 0,9 & Postgraduate & 14 & 6 \\
\hline Working period & & & Job positions & & \\
\hline $0-1$ & 68 & 28,9 & Team leader & 13 & 5,5 \\
\hline $2-3$ & 150 & 63,8 & Quality manager & 3 & 1,3 \\
\hline $4-5$ & 12 & 5,1 & Customer representative & 219 & 93,2 \\
\hline $6-10$ & 1 & 0,4 & & & \\
\hline 10 and over & 4 & 1,7 & & & \\
\hline
\end{tabular}

$56,2 \%$ of the participants are women, $43,8 \%$ are men, and $55,7 \%$ are between the ages of 26-32. Accordingly, it is seen that the average number of employees in the call center is young and women. It has been found that approximately $82 \%$ of the participants are at the associate degree and undergraduate level, the working period of the majority varies between two and three years $(63,8 \%)$ and the customer representa- 
tives mostly $(93,2 \%)$ participate. When the experience of the participants working in the same sector was evaluated, it was concluded that $66 \%$ of them did not have experience in this sector.

According to the results of the factor analysis conducted to evaluate the explanatory power of the scale, there are five factors (tangibles, reliability, responsiveness, assurance and empathy) with an Eigenvalue greater than one and these five factors explain about $62,8 \%$ of the total variance. It is shown in table 2.

Table 2. Total variance explained by factor analysis

\begin{tabular}{|c|c|c|c|c|c|c|}
\hline \multicolumn{4}{|c|}{ Initial Eigenvalues } & \multicolumn{3}{|c|}{ Extraction Sums of Squared Loadings } \\
\hline Componen & it Total & of Variance $(\%)$ & Cumulative (\%) & Total & of Variance $(\%)$ & Cumulative (\%) \\
\hline 1 & 7,365 & 33,476 & 33,476 & 3,522 & 16,011 & 16,011 \\
\hline 2 & 2,518 & 11,445 & 44,921 & 2,992 & 13,600 & 29,611 \\
\hline 3 & 1,602 & 7,284 & 52,205 & 2,848 & 12,947 & 42,558 \\
\hline 4 & 1,220 & 5,544 & 57,749 & 2,683 & 12,193 & 54,752 \\
\hline 5 & 1,100 & 5,000 & 62,748 & 1,759 & 7,997 & 62,748 \\
\hline
\end{tabular}

The results of the Kaiser Meyer Olkin test, which determines whether the sample size taken is sufficient or not, and the Bartlett's test, which express the significance of the result, are shown in table 3.

Table 3. Kaiser-Meyer-Olkin (KMO) and Bartlett's test results

\begin{tabular}{lll}
\hline Kaiser-Meyer-Olkin & Measure of Sampling Adequacy & $\mathbf{0 , 8 5 1}$ \\
\hline \multirow{3}{*}{ Bartlett's Test } & Chi-square & 2433,819 \\
& Df & 231 \\
& Sig. &, 000 \\
\hline
\end{tabular}

In order for the sample size to be sufficient, the Kaiser-Meyer-Olkin test must be greater than 0,5 , and the Bartlett's test must be zero for the significance of the result. According to table 3, the sample is large enough $(0,851>0,5)$ since the result of the KMO sampling adequacy criterion analysis was 0,851 . The result is meaningful because the result of Bartlett's test is also zero.

As a result of the reliability analysis of the service quality scale conducted to test the measurement reliability in this study, Cronbach's Alpha coefficient was 0,922 throughout the scale. The results of the reliabil- 
ity analysis made for the sub-dimensions of expected and perceived quality on a factor basis are shown in table 4 .

Table 4. Reliability analysis results of sub-dimensions

\begin{tabular}{lll}
\hline Dimensions & Sub-dimensions & Cronbach's Alpha coefficient \\
\hline \multirow{4}{*}{ Perceived Quality } & Tangibles &, 824 \\
& Reliability &, 837 \\
& Responsiveness &, 693 \\
& Assurance &, 777 \\
& Empathy &, 770 \\
\hline \multirow{4}{*}{ Expected Quality } & Tangibles &, 549 \\
& Reliability &, 744 \\
& Responsiveness &, 701 \\
& Assurance &, 829 \\
& Empathy &, 804 \\
\hline
\end{tabular}

According to table 4, considering that the Cronbach's Alpha reliability coefficient is high and the reliability level of the scale increases as it approaches one, it is seen that the reliability level of the study is high for each sub-dimension. According to the servqual scores, the difference between the perceptions and expectations of the respondents for each item in the scale is calculated and decided accordingly. In the study, servqual scores according to the sub-dimensions in each dimension calculated using:

Servqual Score $=$ Perception Score - Expectation Score

In table 5, servqual scores and general scores of each sub-dimension are shown together with the average and standard deviations of the perceived and expected service quality.

Table 5. Expectation and perception mean scores of sub-dimensions and servqual scores

\begin{tabular}{|c|c|c|c|c|c|c|c|}
\hline \multirow{2}{*}{ 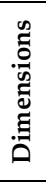 } & \multirow{2}{*}{ Questions } & \multicolumn{2}{|c|}{$\begin{array}{l}\text { Perceived } \\
\text { Values }\end{array}$} & \multicolumn{2}{|c|}{$\begin{array}{l}\text { Expected } \\
\text { Values }\end{array}$} & \multirow{2}{*}{$\begin{array}{l}\text { Servqual } \\
\text { Score }\end{array}$} & \multirow{2}{*}{$\begin{array}{l}\text { Sub- } \\
\text { dimension } \\
\text { Servqual } \\
\text { Score }\end{array}$} \\
\hline & & Mean & SD & Mean & SD & & \\
\hline \multirow{4}{*}{ 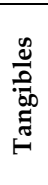 } & Appearance of the equipment & 3,79 & 1,22 & 4,61 & ,78 & $-0,82$ & \multirow{4}{*}{$-0,49$} \\
\hline & View of the facilities & 3,70 & 1,16 & 4,50 & 84 & $-0,8$ & \\
\hline & Employee appearance & 4,15 & ,93 & 4,15 & 1,07 & 0 & \\
\hline & $\begin{array}{l}\text { The attractiveness of the materials } \\
\text { on the services }\end{array}$ & 3,79 & 1,05 & 4,16 & ,96 & $-0,37$ & \\
\hline
\end{tabular}




\begin{tabular}{|c|c|c|c|c|c|c|c|}
\hline \multirow{5}{*}{ 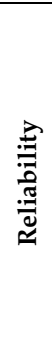 } & $\begin{array}{l}\text { Doing business at the time of com- } \\
\text { mitment }\end{array}$ & 3,98 & 92 & 4,46 & 86 & $-0,48$ & \multirow{5}{*}{$-0,34$} \\
\hline & $\begin{array}{l}\text { Show sincere interest in customers' } \\
\text { problem }\end{array}$ & 4,24 & 88 & 4,49 & 78 & $-0,25$ & \\
\hline & $\begin{array}{l}\text { Getting the service right the first } \\
\text { time }\end{array}$ & 4,18 & 84 & 4,60 & 67 & $-0,42$ & \\
\hline & $\begin{array}{l}\text { Performing transactions within the } \\
\text { committed time }\end{array}$ & 4,16 & 91 & 4,45 & 86 & $-0,29$ & \\
\hline & $\begin{array}{l}\text { Error-free business/record keeping } \\
\text { ability }\end{array}$ & 4,15 & 90 & 4,41 & 87 & $-0,26$ & \\
\hline \multirow{4}{*}{ 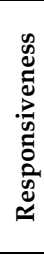 } & $\begin{array}{l}\text { Tell customers exactly when to be } \\
\text { served }\end{array}$ & 4,01 & 1,03 & 4,28 & 94 & $-0,27$ & \multirow{4}{*}{$-0,19$} \\
\hline & $\begin{array}{l}\text { Instant/fast service delivery to } \\
\text { customers }\end{array}$ & 4,21 & 83 & 4,32 & ,95 & $-0,11$ & \\
\hline & Willingness to help customers & 4,29 & 80 & 4,49 & 77 & $-0,2$ & \\
\hline & $\begin{array}{l}\text { Employees are not too busy to } \\
\text { respond to customer requests }\end{array}$ & 4,28 & 91 & 4,46 & 80 & $-0,18$ & \\
\hline \multirow{4}{*}{ 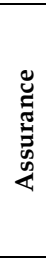 } & $\begin{array}{l}\text { Employee behaviors give confidence } \\
\text { to the customer }\end{array}$ & 4,36 & ,76 & 4,48 & 85 & $-0,12$ & \multirow{4}{*}{$-0,15$} \\
\hline & $\begin{array}{l}\text { Customers feel safe in their transac- } \\
\text { tions }\end{array}$ & 4,30 & 84 & 4,57 & 77 & $-0,27$ & \\
\hline & Be courteous to customers & 4,41 &, 77 & 4,52 & 79 & $-0,11$ & \\
\hline & $\begin{array}{l}\text { Employees have the knowledge to } \\
\text { answer customers' questions }\end{array}$ & 4,49 & 71 & 4,62 & 74 & $-0,13$ & \\
\hline \multirow{5}{*}{ 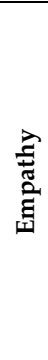 } & $\begin{array}{l}\text { Paying individual attention to } \\
\text { customers }\end{array}$ & 3,71 & 1,18 & 3,97 & 1,18 & $-0,26$ & \multirow{5}{*}{$-0,08$} \\
\hline & $\begin{array}{l}\text { Having convenient operating hours } \\
\text { for customers }\end{array}$ & 4,41 & 95 & 4,47 & 88 & $-0,06$ & \\
\hline & $\begin{array}{l}\text { Having employees providing indi- } \\
\text { vidual service to customers }\end{array}$ & 3,66 & 1,36 & 3,80 & 1,31 & $-0,14$ & \\
\hline & $\begin{array}{l}\text { Taking care of customers' best } \\
\text { interests }\end{array}$ & 4,12 & 1,04 & 4,21 & 96 & $-0,09$ & \\
\hline & $\begin{array}{l}\text { Understanding the specific needs of } \\
\text { customers }\end{array}$ & 3,83 & 1,26 & 3,68 & 1,32 & 0,15 & \\
\hline
\end{tabular}

As seen in table 5, employees with perceived service quality have the knowledge to answer the questions of their customers $(4,49)$, behave politely with customers and have working hours suitable for customers $(4,41)$ are the expressions with the highest average. In the expected service quality, employees 'knowledge to answer customers' questions $(4,62)$, equipment appearance $(4,61)$ and correct first time service $(4,60)$ are the expressions with the highest average. Gap scores will allow the service manager to evaluate current service quality and gauge any gaps that exist. The lower the score, the lower the performance. The gap scores for the five dimensions all ended negatively. This result shows 
that the expectations of front office workers are not actually met. It is seen that the highest servqual scores calculated by the difference of the employees' perception and expectation averages are the tangibles $(-0,49)$ and the lowest score is empathy $(-0,08)$. Figure 2 shows to what extent each sub-dimension does not meet the expectations of the employees, respectively.

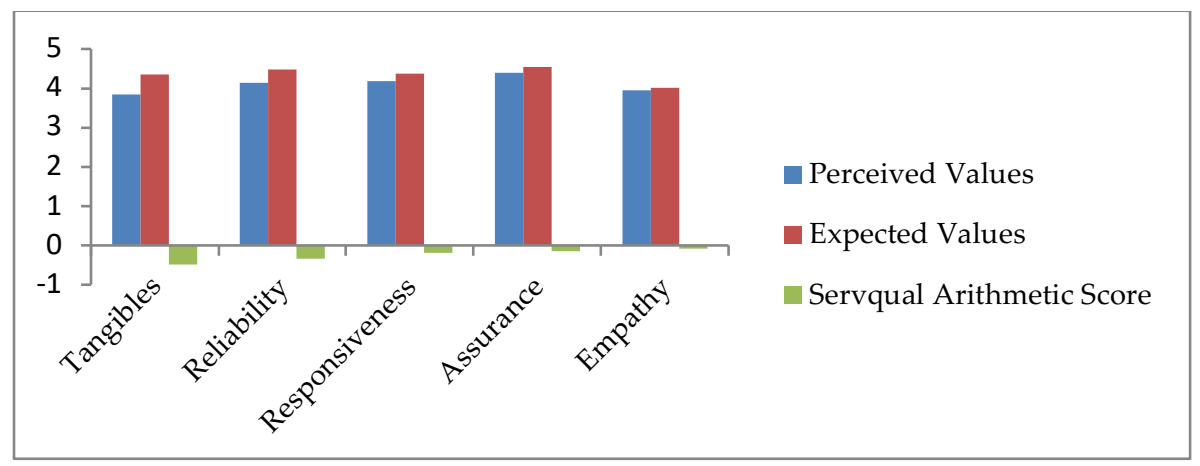

Figure 2. Perceived and expected averages and servqual arithmetic score by service quality dimensions

As seen in figure 2, perception scores remained below the expectation scores in all dimensions. Paired sample t-test was performed to test the difference between expectations (E) and perceptions (P) and to evaluate whether the difference is random or caused by any problem. Results are shown in table 6.

Table 6. Paired sample t-test results

\begin{tabular}{lccccccc}
\hline Paired Sub-Dimensions & Mean & SD & SE & $\begin{array}{l}\text { Gap } \\
\text { Mean }\end{array}$ & t & df & Sig. \\
\hline (E) Tangibles - (P) Tangibles &, 49 &, 98 &, 06 & $-0,49$ & 7,77 & 234 &, 00 \\
(E) Reliability - (P) Reliability &, 33 &, 70 &, 04 & $-0,34$ & 7,36 & 234 &, 00 \\
(E) Responsiveness - (P) Responsive- &, 18 &, 63 &, 04 & $-0,19$ & 4,54 & 234 &, 00 \\
ness & & & & & & & \\
(E) Assurance - (P) Assurance &, 15 &, 63 &, 04 & $-0,15$ & 3,71 & 234 &, 00 \\
(E) Empathy - (P) Empathy &, 07 &, 66 &, 04 & $-0,08$ & 1,75 & 234 &, 08 \\
\hline
\end{tabular}

According to table 6, the differences in question; tangibles, reliability, responsiveness and assurance sub-dimensions are statistically significant at $p<0,05$ significance level, whereas the difference in empathy dimen- 
sion is not statistically significant at $p>0,05$ significance level. In addition, it is observed that the average gap score for tangibles $(-0,49)$ is higher than the other dimensions, and the dimensions of reliability $(-0,34)$, responsiveness $(-0,19)$ and assurance $(-0,15)$ are respectively. The results of the correlation analysis made to evaluate the relationships between expected and perceived service quality dimensions and demographic characteristics are also shown in table 7.

Table 7. Relationships between expected and perceived service quality dimensions and demographic characteristics

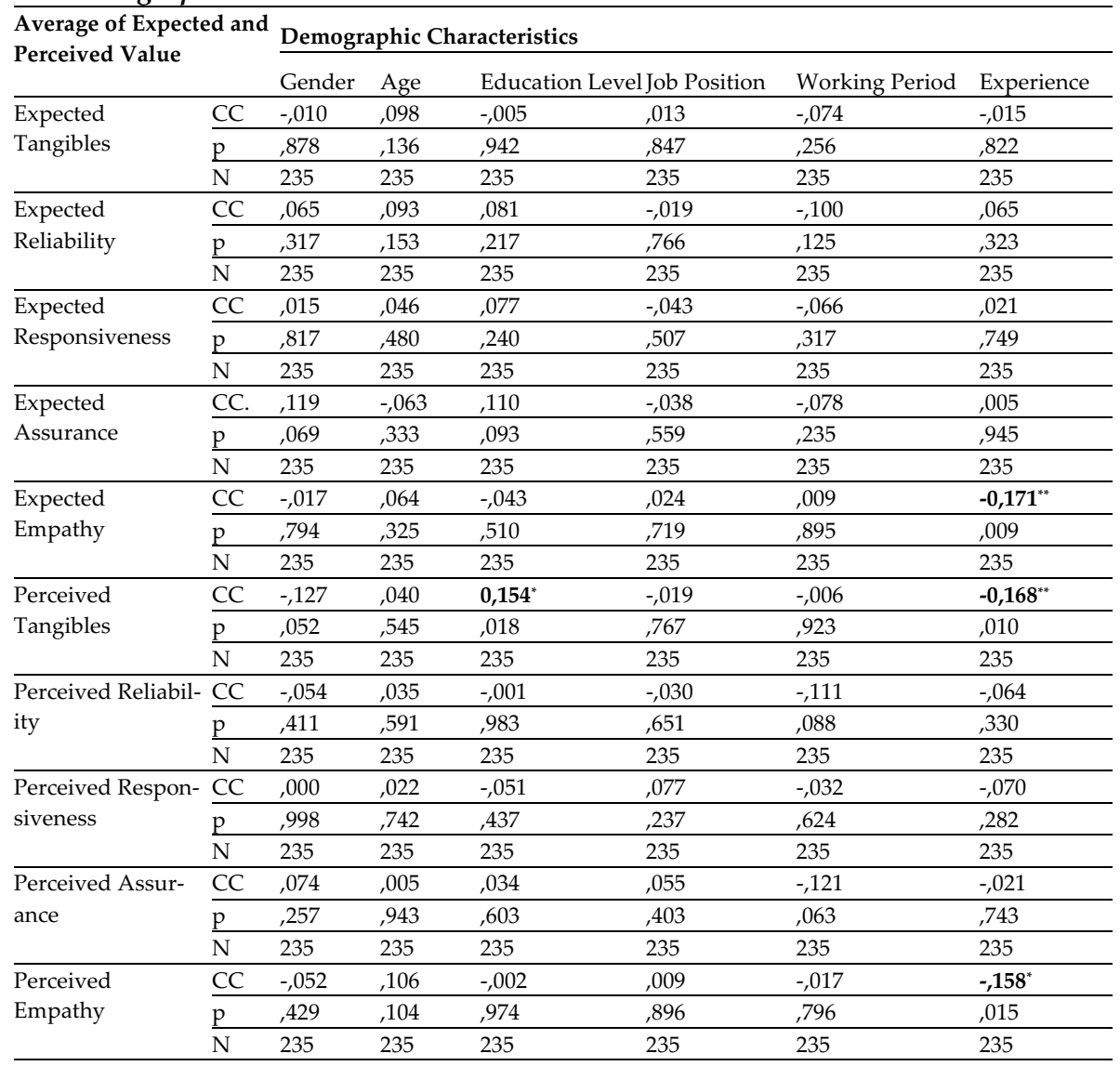

${ }^{* *} p<0,01 ;{ }^{*} p<0,05$ 
According to table 7 , it is seen that there is a negative significant relationship $\left(-0,171^{* *}, p<0,05\right)$ between expected empathy and experience. It is seen that there is a positive and significant relationship $\left(0,154^{*}, \mathrm{p}<0,05\right)$ between perceived tangibles and education level. It is seen that there is a significant negative correlation $\left(-0,168^{* *}, \mathrm{p}<0,01\right)$ between perceived tangibles and experience. It is seen that there is a significant negative correlation $\left(-0,158^{* *}, \mathrm{p}<0,05\right)$ between perceived empathy and experience.

The factors that are effective in improving the service quality in the call center according to the point of view of the employees are evaluated over the average of the answers given to the questions shown in table 8 .

Table 8. Average scores of the elements effective in improving service quality

\begin{tabular}{ll}
\hline Questions & $\begin{array}{l}\text { Mean } \\
\text { Score }\end{array}$ \\
\hline $\begin{array}{l}\text { View of the physical facilities, equipment and staff of the call center } \\
\text { The call center treats its customers with care and special attention to the person }\end{array}$ & 21,34 \\
20,52 \\
$\begin{array}{l}\text { The knowledge and courtesy of call center employees and their ability to make } \\
\text { customers feel a sense of trust }\end{array}$ & 19,70 \\
$\begin{array}{l}\text { The call center's ability to deliver the promised service reliably and accurately } \\
\text { The call center's willingness to assist the customer and the speed of the service } \\
\text { provided }\end{array}$ & 19,53 \\
\hline
\end{tabular}

According to table 8, each element has close average values. According to the responses given by the employees, the highest average value $(21,34)$ was found to be the appearance of the physical facilities, equipment and personnel of the call center.

\section{Discussion and Conclusion}

The servqual applied by adapting it to the call center, according to its dimensions (tangibles, reliability, responsiveness, assurance and empathy), the evaluations of the employees who provide front office service at a state-owned bank's call center were calculated on the gap scores between their perceptions and expectations. Calculated gap scores are a useful tool for managers to identify service deficiencies and are used in planning the measures to be taken. In terms of providing services in different regions, managers have a hard time developing a common under- 
standing of quality in call centers. In this case, managers continue their continuous improvement efforts in terms of quality by obtaining the opinions of both their customers and employees they serve. The perceptions of the employees responsible for the customer service process regarding the service quality significantly affect the service quality provided to the customer. When the results obtained from the data of the study conducted for this purpose are analyzed, the majority of the participants are university graduates $(82 \%)$, who do not have any previous experience in this sector (66\%), have been working in the institution for a short time $(63,8 \%)$, young $(55,7 \%)$ and customer representative $(93,2 \%)$ women $(56,2 \%)$. Accordingly, it is observed that young and university graduates are preferred for the recruitment of call center employees, with low expectation of having experience in this sector. The fact that the questionnaire's explanatory power is $62,8 \%$ over five dimensions (tangibles, reliability, responsiveness, assurance and empathy) and the reliability coefficient is 0,922 across the scale shows that the sufficient explanatory power of the scale is reliable. At the end of the study, the perception scores of the employees were; it was concluded that the tangibles $(-0,49)$, reliability $(-0,34)$, responsiveness $(-0,19)$ and assurance $(-0,15)$ dimensions were statistically significant, and the result for the empathy dimension was not statistically significant. Accordingly, it can be said that the measures to be taken in terms of improvement of service levels other than the empathy dimension and primarily within the scope of tangibles should be addressed by managers. According to this result, it is seen that the service delivery in the call center is carried out in a virtual environment where the customers do not interact with the physical environment, but the employees attach importance to concrete elements. For this reason, it is necessary to be more careful about the appearance of the equipment, facility, materials and employees in the call center.

The results obtained by descriptive statistical analysis are the expressions with the highest average, according to both perceived $(4,49)$ and expected $(4,62)$ service quality averages. Accordingly, it can be said that employees are strong within the scope of this variable, but they want to be stronger. According to this result, managers should organize training programs to ensure that employees have sufficient knowledge and skill levels. For example, the call center should develop training strategies to 
improve the skills of front office employees to provide safe and fast service. Employees, whose knowledge and skill level has improved in service delivery, will solve customers' problems quickly and effectively, thus improving the service quality offered.

According to the results of the correlation analysis conducted to evaluate the relationships between expected and perceived service quality dimensions and demographic characteristics, there was a positive significant relationship $\left(0,154^{*}, \mathrm{p}<0,05\right)$ between the perceived tangibles and the education level. For this reason, the improvement in tangibles is considered more important with the increase in the education level. Considering that the employees at the call center where the application is made have undergraduate education and the highest difference score $(-0,49)$ in terms of concrete characteristics, managers should take this situation into consideration and take measures. The fact that the highest average value $(21,34)$ is in tangibles dimension as a result of evaluating the factors that are effective in improving the service quality in the call center by the employees over 100 points reveals that this dimension should be especially considered by the managers. These results are interpreted according to the perspectives of employees at a bank's call center. The evaluation of the service quality of the employees will enable service organizations to design the service delivery process effectively and efficiently, thus providing better service to the customers served.

\section{References}

Chicu, D., Ryan, G. and Aparicio, M. V. (2016). Determinants of customer satisfaction in call centres. European Accounting and Management Review Issue, 2(21), 20-4.

Dean, A. M. and Rainnie, A. (2009). Frontline employees' views on organizational factors that affect the delivery of service quality in call centers. Journal of Services Marketing, 23(5), 326-337.

Gümüş, M. (2002). Günümüzün gelişen sektörü çağrı merkezleri. SAÜ Fen Bilimleri Enstitüsü Dergisi, 6(2), 134-141.

Jaiswal, A. K. (2008). Customer satisfaction and service quality measurement in Indian call centres. Managing Service Quality: An International Journal, 18(4), 405-416. 
Lovelock, C. and Wright, L. (1999). Principles of service marketing and management. Upper Saddle River, NJ: Prentice Hall.

Kocabaş, İ. (2017). Çağrı merkezi müşteri temsilcisinin imajının müşteri memnuniyeti üzerindeki rolü. Gümüşhane Üniversitesi İletişim Fakültesi Elektronik Dergisi, 5(1), 118-147.

Munhurrun, P. R., Naidoo, P. and Bhiwajee, S. D. L. (2009). Employee perceptions of service quality in a call centre. Managing Service Quality, 19(5), 541-557.

Osahon, O. J. and Kingsley, O. (2016). Statistical approach to the link between internal service quality and employee job satisfaction: A case study. American Journal of Applied Mathematics and Statistics, 4(6), 178-184.

Prabhaker, P. R., Sheehan M. J. and Coppett, J. I. (1997). The power of technology in business selling: Call centers. Journal of Business $\mathcal{E}$ Industrial Marketing, 12(3/4), 222-235.

Parasuraman, A., Berry, L. L. and Zeithaml, V. A. (1991). Refinement and reassessment of the servqual scale. Journal of Retailing, 67(4), 420-450.

Sarıyer, N. (2007). Çağrı merkezi tüketici profili: Banka çağrı merkezlerinde bir uygulama. Atatürk Üniversitesi Sosyal Bilimler Enstitüsü Dergisi, 10(2), 473-493.

Taşkın, D. and Taşkın, Ç. (2018). Çağrı merkezi hizmetlerinde müşteri beklentisi boyutlarının müşteri tatmini üzerindeki etkisinin PLS-SEM ile ölçümü. Journal of Business Research Turk, 10(1), 465-481.

TÜİK (2018). www.tuik.gov.tr. Erişim: 10 Aralık 2020.

\section{Kaynakça Bilgisi / Citation Information}

Çetindere Filiz, A. ve Atalar, M. (2021). Evaluation of service quality in a call center from the employees perspective. OPUS-International Journal of Society Researches, 18(39), 29-46. DOI: 10.26466/opus. 881444 